\title{
Assessment of Microbial and Heavy Metal Concentration per Distance and Depth at a Municipal Solid Waste Landfill
}

\author{
O. T. Ogunmodede ${ }^{1, *}$, A. A. Ojo ${ }^{1}$, O. L. Adebayo ${ }^{2}$ \\ ${ }^{1}$ Chemical Sciences Department, Afe Babalola University, Ado-Ekiti, Ekiti State, Nigeria \\ ${ }^{2}$ Department of Chemistry, College of Education, Ikere Ekiti, Nigeria \\ *E-mail address: taiwokehindelolade@gmail.com
}

\begin{abstract}
The field study involved 4 sites and 15 samples according to the wind directions: North, East, South and West. The analysis was conducted through the use of Atomic Absorption spectroscopy (AAS). Ten types of heavy metals were identified as indicators for pollution namely $\mathrm{Mg}, \mathrm{Ca}, \mathrm{Mn}, \mathrm{Fe}$, $\mathrm{Cu}, \mathrm{Zn}, \mathrm{Pb}, \mathrm{Ni}, \mathrm{Cr}$, and $\mathrm{Cd}$. The results indicated that the concentration of $\mathrm{Fe}$ was the most dominant per specific distances and depths and exceeded the minimum standard in North, East and West directions. While $\mathrm{Cu}$ was the second most dominant with concentration exceeding minimum standard per specific distance and depth, mainly in the West direction. The results have shown presence of bacterial species including Pseudomonas, Mirococcus, Actinomyces, Neisseria, Bacillus and Klebsiella. These pathogens can infect wounds and cause sepsis and mortality and can even occur with such organisms to cause secondary infection. These groups of organisms are almost impossible to control since they are ubitiquous.
\end{abstract}

Keywords: Heavy metals; land contaminated; open landfill site; bacterial

\section{INTRODUCTION}

Soil is a vital resource for sustaining basic human needs, a quality food supply and a livable environment (1). It serves as a sink and recycling factory for both liquid and solid wastes. Municipal solid waste has been found to contain appreciable quantity of heavy metals such as $\mathrm{Cd}, \mathrm{Zn}, \mathrm{Pb}$, and $\mathrm{Cu}$, all which may eventually end - up in the soil and are leached down the profile (2). This qualifies municipal solid wastes among the principal sources of heavy metals in the environment. Other identifiable sources include atmospheric deposition, manure and fertilizers, pesticides and industrial discharge (3). The concern about these heavy metals is that they are not biodegradable and may therefore accumulate in the environment. Thus, one of the development challenges facing this decade is how to achieve a cost effective and environmentally sound strategies to deal with the global waste crisis facing both the developed and developing countries (4). The crisis has threatened the assimilative and carrying capacity of the earth, which is our life support system. Studies on heavy metals (density $>5.54 \mathrm{gcm}-3$ ) in ecosystem have shown an indication of a silent epidemic of environmental metal poisoning of ever increasing metals in sub humid tropical soils (5). With increasing pressure on agricultural and the proliferation of urban and peri-urban farming, waste dump sites are becoming attractive because of their rich deposits of organic matter and 
plant nutrients. Although the nutrient content of wastes makes them attractive as fertilizers, land application of many industrial wastes and sewage is constrained by the presence of heavy metals, hazardous organic chemicals, salts, and extreme $\mathrm{pH}(6)$.

Heavy metal pollution is a component of environmental pollutant closely related to human activities. Studies on the pollution have been conducted by various researchers of various fields such as chemistry, biology, geography, engineering and environment. Among studies on the heavy metal pollution were those conducted by (7), (8), and (9). Other than general studies on heavy metal, heavy metal pollution studies also covered various sources of ecosystem such as the aquatic ecosystem (10) and terrestrial ecosystem (11). Studies on heavy metal pollution also combined analysis of specific metal concentration and aspects on management of the sources of pollution. Examples are studies on relationship between heavy metal pollution and its management and specific study on factors influencing distribution, management and control of heavy metal pollution was conducted by (12). Therefore, the objective of this study was to examine the effects of municipal solid waste open dump site on soil physic-chemical properties and therefore to assess the occurrence of microbial pathogens of waste dumpsite per the distance and depth of up to $30 \mathrm{~cm}$ from the soil surface around the landfill and discuss its impact on public health.

\section{MATERIALS AND METHODS}

The location of the dumpsite was at altitude $\mathrm{N} 7^{\circ} 37.064^{1}, \mathrm{E} 5^{\circ} 15.134^{1}$ and $\mathrm{N} 7^{\circ} 37.059^{1}$, E5 ${ }^{\circ} 15.138^{1}$ at the Odo Aremu dumpsite, Ado Ekiti Nigeria. The geology of the area forms a complex pattern of coarse and fined grained gneisses. The soil is derived from material of the old basement complex, which is mainly made up of granitic metamorphosed sedimentary rock. The dumpsites have been existing for over 50 years. The sampling was done in parallel according to the distance from the dumpsite, leading outward with the marked distances of 0 , 10, and $20 \mathrm{~m}$, respectively. The soil samplings were taken using Auger instrument and the depth of the soil per soil surface was marked at 0 and $30 \mathrm{~cm} .50 \mathrm{~g}$ of the soil was taken from each point from the depths and distance prescribed. The soil samples were equally analysed for the following parameters: organic matter, particle size, exchangeable cations, $\mathrm{pH}$ and heavy metals content. Soil organic matter was determined, particle size distribution was determined by the hydrometer method using sodium hexametaphosphate as the dispersant, exchangeable bases were extracted with ammonium acetate at $\mathrm{pH} 7$ and the $\mathrm{Ca}, \mathrm{Na}$ and $\mathrm{K}$ contents of the extracts were determined with a Jenway flame photometer while the Ca, and $\mathrm{Mg}$ contents were determined using AAS. Heavy metals were extracted using a mixture of 1 $\mathrm{ml} \mathrm{HNO}_{3}$ and $3 \mathrm{ml}$ of $\mathrm{HCl}$ (aqua regia) and the content heated on a hot plate in a fume cupboard to dryness at $105{ }^{\circ} \mathrm{C}$, allowed to cool and leached with $0.5 \mathrm{M} \mathrm{HCl}$ before analysis using a Perkin Elmer Atomic Absorption Spectrophotometer (AAS) as described (13).

\section{1. Microbial Analysis}

$10 \mathrm{~g}$ of five soils from each sample was thoroughly shaken in $10 \mathrm{ml}$ of sterile normal saline. $1.0 \mathrm{ml}$ of soil sample was transferred into the next tube and diluted serially in a one tenth step wise to $10^{-17}$ dilution. The organism were isolated and identified using standard Bacteriological methods. Each sample $(10 \mathrm{~g})$ of fine soil was thoroughly shaken in $10 \mathrm{ml}$ of sterile distilled water. Aliquot $(1.0 \mathrm{ml})$ of it was transferred into next test - tube and diluted serially in one - tenth stepwise to $10^{-4}$ dilution. From the dilution of $10^{-3}$ of each soil sample, $0.1 \mathrm{ml}$ aliquot was transferred aseptically onto freshly prepared dextrose agar plates to which 
$0.2 \mathrm{ml}$ of $0.5 \%$. Ampicillin has been added to inhibit the growth of bacteria and allowing the growth of fungi (14). The inoculums were spread with a sterile bent glass rod. The dilution of $10^{3}$ was used in planting for fungi because the dilution of $10^{-4}$ gave fewer growths. The inoculated plates were inverted and incubated at $28^{\circ} \mathrm{C}$ (room temperature) for 5 to 7 days.

The colonies which developed were counted and counts for duplicate cultures were recorded as total viable fungi in the sample.

Geoaccumulation index ( $\left.\mathbf{I}_{\mathbf{G E O}}\right)$ was use in determining metal pollution in soils following the formula proposed by (15). It is expressed as

$$
\text { Igeo }=\log 2 \mathrm{Cm} / 1.5 \mathrm{Bn} \text { or } \ln (\mathrm{Cn} / 1.5 \mathrm{Bn})
$$

where:

$\mathrm{Cm}=$ Measured concentration at sampling point

$\mathrm{Bn}=$ Background concentration value for the element

$1.5=$ the background matrix correction factor due to lithogenic effects.

The geoaccumulation index consists of seven grades (0-5) ranging from uncontaminated to very highly contaminate ( 15$)$. These seven descriptive classes are as follows;

$<0=$ practically uncontaminated

$0-1=$ uncontaminated to slightly contaminated

1-2 = moderately contaminated

2-3 = moderately to highly contaminated

3-4 = highly contaminated

$4-5=$ highly to very highly contaminated

$>5=$ very highly/strongly contaminated

The control samples were taken to represent the background.

Table 1. Description of the site.

\begin{tabular}{|c|c|c|c|c|}
\hline Town & $\begin{array}{c}\text { Description of } \\
\text { Location }\end{array}$ & $\begin{array}{c}\text { Geo-position system } \\
\text { (GPS) }\end{array}$ & Type & Age (years) \\
\hline Odo Aremu & North & $\begin{array}{l}\mathrm{N} 7^{\circ} 37.062^{1} \\
\mathrm{E} 5^{\circ} 15.134^{1}\end{array}$ & $\begin{array}{r}\text { Domestic, } \\
\text { mechanic } \\
\text { dumpsite }\end{array}$ & $\geq 30$ \\
\hline Odo Aremu & East & $\begin{array}{l}\mathrm{N} 7^{\circ} 37.064^{1} \\
\mathrm{E} 5^{\circ} 15.134^{1}\end{array}$ & $\begin{array}{c}\text { Domestic, } \\
\text { mechanic } \\
\text { dumpsite }\end{array}$ & $\geq 30$ \\
\hline Odo Aremu & South & $\begin{array}{l}\mathrm{N} 7^{\circ} 37.063^{1} \\
\mathrm{E} 5^{\circ} 15.133^{1}\end{array}$ & $\begin{array}{c}\text { Domestic, } \\
\text { dumpsite }\end{array}$ & $\geq 30$ \\
\hline Odo Aremu & West & $\begin{array}{l}\mathrm{N}^{\circ} 37.059^{1} \\
\mathrm{E}^{\circ} 15.138^{1}\end{array}$ & $\begin{array}{c}\text { Domestic, } \\
\text { mechanic } \\
\text { dumpsite }\end{array}$ & $\geq 30$ \\
\hline
\end{tabular}


Table 2. Allowable Limits of Metal Concentrations in Soil (mg/kg).

\begin{tabular}{|c|c|c|c|c|c|c|c|}
\hline $\begin{array}{c}\text { Heavy } \\
\text { metal } \\
(\mathrm{mg} / \mathrm{kg})\end{array}$ & Austria & Germany & France & Denmark & Netherlands & Sweden & $\begin{array}{c}\text { Spain } \\
(\mathrm{pH}<7)\end{array}$ \\
\hline $\mathrm{Cd}$ & $1-2$ & 1 & 2 & 0.5 & 0.5 & 0.4 & 1 \\
\hline $\mathrm{Cr}$ & 100 & 60 & 150 & 30 & 30 & 60 & 100 \\
\hline $\mathrm{Co}$ & 50 & - & - & - & - & - & - \\
\hline $\mathrm{Ni}$ & $50-70$ & 50 & 50 & 15 & 15 & 30 & 30 \\
\hline $\mathrm{Pb}$ & 100 & 70 & 100 & 40 & 40 & 40 & 50 \\
\hline
\end{tabular}

Source: ECDGE (2004)

\section{RESULTS}

\section{1. Concentration of heavy metal in North direction}

Table 3 shows the results of the analysis for the concentration of the heavy metals per the distance and depths detected at the site the North direction of the dumpsite. Generally, the concentration of Fe was dominant for all distances and depths compared to other metals. The concentrations per distances for $0 \mathrm{~cm}, 10 \mathrm{~cm}$ and $20 \mathrm{c} \mathrm{m}$ were respectively at $3973.44,3058.18$ and 2869.12 respectively. The Fe concentration detected exceeded minimum standard this might be as a result of background concentration of Iron. It has been confirmed that natural soils contains significant concentration of iron (16). (17) suggested that the pollution of the environment by iron cannot be conclusively link to waste materials alone but other natural sources of iron must be taken into consideration. The second highest concentration was $\mathrm{Cu}$ at $540.13 \mathrm{mg} / \mathrm{kg}$ at the depth of $30 \mathrm{~cm}$ at $0 \mathrm{~m}$ from the landfill. This was caused by soil properties around the north side of station which contained calcite, gypsum and fluorite containing calcium carbonate. For $\mathrm{Ni}, \mathrm{Cd}, \mathrm{Mn}, \mathrm{Zn}$ and $\mathrm{Pb}$, the lab analysis indicated that their concentration were very low for every distance and depth.

Table 3. Heavy metal concentration based on distance and depth from landfill (North direction).

\begin{tabular}{|c|c|c|c|c|}
\hline Parameter & $\begin{array}{c}\text { Distance 0 } \\
\text { Depth 0 }-30 \mathrm{~cm}\end{array}$ & $\begin{array}{c}\text { Distance } 10 \mathrm{~m} \\
\text { Depth 0 -30 cm }\end{array}$ & $\begin{array}{c}\text { Distance 20 m } \\
\text { Depth 0 }-30 \mathrm{~cm}\end{array}$ & $\begin{array}{c}\text { Control } \\
0-30 \mathrm{~cm}\end{array}$ \\
\hline $\mathrm{Ca}(\mathrm{mg} / \mathrm{kg})$ & $16.44 \pm 0.02$ & $14.75 \pm 0.01$ & $11.86 \pm 0.02$ & $3.68 \pm 0.04$ \\
\hline $\mathrm{Mg}(\mathrm{mg} / \mathrm{kg})$ & $22.22 \pm 0.02$ & $20.89 \pm 0.07$ & $18.14 \pm 0.03$ & $1.16 \pm 0.01$ \\
\hline $\mathrm{Na}(\mathrm{mg} / \mathrm{kg})$ & $21.04 \pm 0.01$ & $20.06 \pm 0.02$ & $19.35 \pm 0.01$ & $1.31 \pm 0.03$ \\
\hline $\mathrm{Pb}(\mathrm{mg} / \mathrm{kg})$ & $181.00 \pm 0.62$ & $128.11 \pm 0.01$ & $113.02 \pm 0.01$ & $118.72 \pm 0.06$ \\
\hline $\mathrm{Ni}(\mathrm{mg} / \mathrm{kg})$ & $108.22 \pm 0.01$ & $86.58 \pm 0.04$ & $64.40 \pm 0.01$ & $19.96 \pm 0.12$ \\
\hline $\mathrm{Cr}(\mathrm{mg} / \mathrm{kg})$ & $116.33 \pm 0.11$ & $102.39 \pm 0.07$ & $84.22 \pm 0.04$ & $8.75 \pm 0.01$ \\
\hline $\mathrm{Cd}(\mathrm{mg} / \mathrm{kg})$ & $10.16 \pm 0.02$ & $10.03 \pm 0.01$ & $8.32 \pm 0.06$ & $0.10 \pm 0.00$ \\
\hline $\mathrm{Cu}(\mathrm{mg} / \mathrm{kg})$ & $540.13 \pm 0.03$ & $485.80 \pm 0.01$ & $219.65 \pm 0.03$ & $30.50 \pm 0.01$ \\
\hline $\mathrm{Fe}(\mathrm{mg} / \mathrm{kg})$ & $3973.44 \pm 1.04$ & $3058.18 \pm 2.02$ & $2869.12 \pm 1.04$ & $1593.50 \pm 1.02$ \\
\hline $\mathrm{Zn}(\mathrm{mg} / \mathrm{kg})$ & $261.36 \pm 0.02$ & $180.87 \pm 0.03$ & $101.20 \pm 0.01$ & $99.25 \pm 0.01$ \\
\hline $\mathrm{Mn}(\mathrm{mg} / \mathrm{kg})$ & $498.37 \pm 0.03$ & $410.14 \pm 0.02$ & $384.33 \pm 0.03$ & $92.36 \pm 0.03$ \\
\hline $\mathrm{N}(\mathrm{cmol} / \mathrm{kg})$ & $0.16 \pm 0.02$ & $0.11 \pm 0.02$ & $0.11 \pm 0.01$ & $0.12 \pm 0.02$ \\
\hline
\end{tabular}




\section{2. The concentration of heavy metal in the east direction}

Based on the lab analysis, the concentration of heavy metals in the eastern side showed similar trend per distance and depth as the results for the northern side. The concentration of Fe was found dominant towards the East at $30 \mathrm{~cm}$ depth. Table 4 shows the high Fe concentration for all depths per the distances. An example is at 10, the concentration of Fe was at $4236.12 \pm 2.72 \mathrm{mg} / \mathrm{kg}$. Meanwhile the concentration of Fe at $20 \mathrm{~cm}$ exceeded minimum standard. The lab analysis also indicated that the $\mathrm{Cu}$ concentration was a little higher compared to $\mathrm{Mg}, \mathrm{Ca}, \mathrm{Mn}, \mathrm{Zn}$ and $\mathrm{Pb}$. High $\mathrm{Cu}$ concentration was detected at the surface level at distance $0 \mathrm{~cm}$ from the landfill $(548.80 \mathrm{mg} / \mathrm{kg})$, which exceeded the minimum standard. High concentration of the $\mathrm{Cu}$ was due to the presence of electronic wastes such as disused wires in the eastern side of the landfill.

Concentration of $\mathrm{Ni}$ was found highest at a distance of $0 \mathrm{~cm}$ of soil surface (116.41 $\mathrm{mg} / \mathrm{kg})$ and at distance of $10 \mathrm{~cm}$ with a depth of $30 \mathrm{~cm}(98.70 \mathrm{mg} / \mathrm{kg})$. The Ni concentration for both distances exceeded the minimum standard $(0.9 \mathrm{mg} / \mathrm{kg})$ set by FEPA. The presence of $\mathrm{Ni}$ in the area was influenced by the small scale industrial environment. Hence this condition directly affected the concentration of $\mathrm{Ni}$ in the soil. Henceforth, the mean analysis of $\mathrm{Mn}$ and $\mathrm{Zn}$ indicated that both metals had lowest concentration in the soil. Laboratory analysis indicated that at all depths and distances from the landfill, both heavy metals were weighed less than $1 \mathrm{ml} / \mathrm{g}$.

Analytical results indicated that in the values for $\mathrm{Cd}, \mathrm{Cu}, \mathrm{Cr}, \mathrm{Zn}, \mathrm{Co}$ and $\mathrm{Pb}$ were grossly above the literature levels of a typical soil. The high level for $\mathrm{Cu}(116.41 \mathrm{mg} / \mathrm{kg})$ conforms to a similar finding where a value of $31.2 \mathrm{mg} / \mathrm{kg}$ was reported for $\mathrm{Cu}$ in landfill soil in Ibadan in South-West Nigeria (18)

Table 4. Heavy metal concentration based on distance and depth from landfill (East direction).

\begin{tabular}{|c|c|c|c|c|}
\hline Parameter & $\begin{array}{c}\text { Distance 0 } \\
\text { Depth 0 }-30 \mathrm{~cm}\end{array}$ & $\begin{array}{c}\text { Distance } 10 \mathrm{~m} \\
\text { Depth } 0-30 \mathrm{~cm}\end{array}$ & $\begin{array}{c}\text { Distance } 20 \mathrm{~m} \\
\text { Depth } 0-30 \mathrm{~cm}\end{array}$ & $\begin{array}{c}\text { Control } \\
0-30 \mathrm{~cm}\end{array}$ \\
\hline $\mathrm{Ca}(\mathrm{mg} / \mathrm{kg})$ & $6.64 \pm 0.02$ & $6.02 \pm 0.03$ & $5.82 \pm 0.03$ & $1.12 \pm 0.02$ \\
\hline $\mathrm{Mg}(\mathrm{mg} / \mathrm{kg})$ & $8.86 \pm 0.02$ & $8.11 \pm 0.01$ & $6.43 \pm 0.01$ & $1.02 \pm 0.01$ \\
\hline $\mathrm{Na}(\mathrm{mg} / \mathrm{kg})$ & $7.03 \pm 0.01$ & $6.70 \pm 0.02$ & $6.12 \pm 0.02$ & $1.28 \pm 0.02$ \\
\hline $\mathrm{Pb}(\mathrm{mg} / \mathrm{kg})$ & $179.12 \pm 0.12$ & $131.33 \pm 0.11$ & $122.12 \pm 0$ & $23.42 \pm$ \\
\hline $\mathrm{Ni}(\mathrm{mg} / \mathrm{kg})$ & $116.41 \pm 0.10$ & $98.70 \pm 0.12$ & $87.52 \pm 0.03$ & $21.12 \pm 0.02$ \\
\hline $\mathrm{Cr}(\mathrm{mg} / \mathrm{kg}))$ & $117.12 \pm 0.12$ & $114.81 \pm 0.08$ & $94.81 \pm 0.11$ & $12.04 \pm 0.06$ \\
\hline $\mathrm{Cd}(\mathrm{mg} / \mathrm{kg})$ & $11.30 \pm 0.02$ & $10.82 \pm 0.02$ & $9.14 \pm 0.01$ & $0.14 \pm 0.01$ \\
\hline $\mathrm{Cu}(\mathrm{mg} / \mathrm{kg})$ & $548.80 \pm 0.06$ & $501.04 \pm 0.22$ & $410.22 \pm 0.12$ & $31.25 \pm 0.05$ \\
\hline $\mathrm{Fe}(\mathrm{mg} / \mathrm{kg})$ & $3871.13 \pm 1.13$ & $4236.12 \pm 2.72$ & $4013.15 \pm 1.15$ & $1665.30 \pm 2.04$ \\
\hline $\mathrm{Zn}(\mathrm{mg} / \mathrm{kg})$ & $301.22 \pm 0.04$ & $276.16 \pm 0.02$ & $242.33 \pm 0.03$ & $96.41 \pm 0.01$ \\
\hline $\mathrm{Mn}(\mathrm{mg} / \mathrm{kg})$ & $221.23 \pm 0.03$ & $201.11 \pm 0.01$ & $174.83 \pm 0.01$ & $90.11 \pm 0.01$ \\
\hline $\mathrm{N}(\mathrm{cmol} / \mathrm{kg})$ & $0.36 \pm 0.01$ & $0.31 \pm 0.01$ & $0.28 \pm 0.02$ & $0.21 \pm 0.02$ \\
\hline
\end{tabular}




\section{3. Concentration of Heavy Metal in South Direction}

The lab analysis indicated that $\mathrm{Cu}, \mathrm{Mn}$ and $\mathrm{Fe}$ showed highest concentration at all distances and depths. For instance, the concentration of $\mathrm{Cu}$ was highest at the distance of $0 \mathrm{~cm}$ at the depth of $30 \mathrm{~cm}(549.72 \mathrm{mg} / \mathrm{kg})$. Compared to distance of $10 \mathrm{~m}$ and $20 \mathrm{~m}$, the high concentration of $\mathrm{Cu}$ was at 361.24 and $204.11 \mathrm{mg} / \mathrm{kg}$, respectively. The concentration at distance $10 \mathrm{~m}$ was higher compared to other distances, this occurred due to the influence of the composition of the soil samples mix. Henceforth, the concentration of Fe was dominant at all distances and depths. Based on Table 5, it shows that Fe concentration at distance of $0 \mathrm{~cm}$ was higher than any other distances. The trend was similar to the concentration of $\mathrm{Cu}$ at $10 \mathrm{~m}$, which was due to the composition of soil samples mix. An instance of concentration at $30 \mathrm{~cm}$ depth was $4021.18 \mathrm{mg} / \mathrm{kg}$, the highest concentration of $\mathrm{Fe}$ at $10 \mathrm{~m}$ and for other distances.

Meanwhile, $\mathrm{Pb}, \mathrm{Zn}$ and $\mathrm{Mn}$ indicated high concentrations compared to other heavy metals for all distances and depth around the landfill site. Even though $\mathrm{Cu}$ and $\mathrm{Mn}$ showed slight difference of concentration at distance $10 \mathrm{~m}$ with concentration exceeding $1.0 \mathrm{mg} / \mathrm{kg}$. For $\mathrm{Pb}$, the concentration at $0 \mathrm{~cm}, 10$ and $20 \mathrm{~cm}$ depths were respectively at $187.12,150.22$ and $123.15 \mathrm{mg} / \mathrm{kg}$, respectively which is higher than the minimum allowable limit.

Table 5. Heavy metal concentration based on distance and depth from landfill (South direction).

\begin{tabular}{|c|c|c|c|c|}
\hline Parameter & $\begin{array}{c}\text { Distance 0 } \\
\text { Depth 0 -30 cm }\end{array}$ & $\begin{array}{c}\text { Distance 10 m } \\
\text { Depth 0 -30 cm }\end{array}$ & $\begin{array}{c}\text { Distance 20 m } \\
\text { Depth 0 -30 cm }\end{array}$ & $\begin{array}{c}\text { Control } \\
0-30 \mathrm{~cm}\end{array}$ \\
\hline $\mathrm{Ca}(\mathrm{mg} / \mathrm{kg})$ & $16.73 \pm 0.03$ & $74.20 \pm 0.00$ & $13.14 \pm 0.02$ & $3.63 \pm 0.01$ \\
\hline $\mathrm{Mg}(\mathrm{mg} / \mathrm{kg})$ & $23.62 \pm 0.02$ & $19.41 \pm 0.03$ & $21.02 \pm 0.02$ & $1.21 \pm 0.01$ \\
\hline $\mathrm{Na}(\mathrm{mg} / \mathrm{kg})$ & $21.58 \pm 0.06$ & $18.11 \pm 0.03$ & $17.49 \pm 0.03$ & $1.36 \pm 0.03$ \\
\hline $\mathrm{Pb}(\mathrm{mg} / \mathrm{kg})$ & $187.12 \pm 0.24$ & $150.22 \pm 0.14$ & $123.15 \pm 0.35$ & $18.84 \pm 0.02$ \\
\hline $\mathrm{Ni}(\mathrm{mg} / \mathrm{kg})$ & $112.33 \pm 0.11$ & $106.20 \pm 0.05$ & $84.32 \pm 0.06$ & $19.92 \pm 0.02$ \\
\hline $\mathrm{Cr}(\mathrm{mg} / \mathrm{kg}))$ & $116.95 \pm 0.23$ & $95.54 \pm 0.16$ & $80.61 \pm 0.07$ & $8.93 \pm 0.01$ \\
\hline $\mathrm{Cd}(\mathrm{mg} / \mathrm{kg})$ & $10.55 \pm 0.03$ & $7.33 \pm 0.01$ & $6.12 \pm 0.02$ & $0.10 \pm 0.02$ \\
\hline $\mathrm{Cu}(\mathrm{mg} / \mathrm{kg})$ & $549.72 \pm 0.24$ & $361.24 \pm 0.18$ & $204.11 \pm 0.13$ & $30.52 \pm 0.06$ \\
\hline $\mathrm{Fe}(\mathrm{mg} / \mathrm{kg})$ & $3958.12 \pm 3.22$ & $4021.18 \pm 6.28$ & $3814.06 \pm 4.02$ & $1593.25 \pm 3.15$ \\
\hline $\mathrm{Zn}(\mathrm{mg} / \mathrm{kg})$ & $259.74 \pm 0.12$ & $197.13 \pm 0.03$ & $201.82 \pm 0.08$ & $79.70 \pm 0.02$ \\
\hline $\mathrm{Mn}(\mathrm{mg} / \mathrm{kg})$ & $502.10 \pm 0.00$ & $422.12 \pm 0.22$ & $301.33 \pm 0.11$ & $92.33 \pm 0.13$ \\
\hline $\mathrm{N}(\mathrm{cmol} / \mathrm{kg})$ & $0.18 \pm 0.01$ & $0.11 \pm 0.01$ & $0.12 \pm 0.01$ & $0.10 \pm 0.03$ \\
\hline
\end{tabular}

\section{4. Concentration of heavy metals in west direction}

The West direction concentration of Fe was consistently high at all distances and depths from the landfill (Table 6). The highest concentration of Fe was detected at distances $0 \mathrm{~m}$ and at $30 \mathrm{~cm}$ depth, particularly at $0 \mathrm{~m}$ distance $(4387.52 \mathrm{mg} / \mathrm{kg})$ and $10 \mathrm{~m}(4263.23 \mathrm{mg} / \mathrm{kg})$, respectively. The concentration of Fe for both samples exceeded the minimum FEPA and allowable minimum standard in some country $(4387.52 \mathrm{mg} / \mathrm{kg})$. The effect of Fe occurred due to mechanical work shop process conducted around the landfill site. Meanwhile the $\mathrm{Cu}$ showed high concentration at surface level for every distance. The high $\mathrm{Cu}$ concentration at 0 $\mathrm{m}$ distance $(550.92 \mathrm{mg} / \mathrm{L})$ exceeded the minimum allowable standard in some country (Table 2). High concentration of $\mathrm{Cu}$ at this distance occurred due to the effect of recycling activities nearby the sampling stations, particularly the disintegration of electronic wastes (Table 6). In 
contrast, the $\mathrm{Mg}$ and $\mathrm{Ca}$ concentration was a little higher at distance nearer to the landfill site compared to the farther ones. This occurred due to the influence of drier soil surface nearer to the station vicinity compared to the more watery ones farther outward. The watery condition was a factor which influenced the concentration of the heavy metal for it reduced their viscosity. The metals with the lowest concentration, with less than $10.0 \mathrm{mg} / \mathrm{kg}$ were $\mathrm{Mg}, \mathrm{Ca}$ and $\mathrm{Na}$. Based on Table 6, the laboratory analysis of surface soil around the landfill vicinity for all distances indicated the concentration of $\mathrm{Mn}$ to highest at distance $0 \mathrm{~m}$ and depth $30 \mathrm{~cm}$ $(221.36 \mathrm{mg} / \mathrm{kg})$ which exceeded the minimum standard, set by FEPA.

Table 6. Heavy metal concentration based on distance and depth from landfill (West direction).

\begin{tabular}{|c|c|c|c|c|}
\hline Parameter & $\begin{array}{c}\text { Distance 0 } \\
\text { Depth 0-30 cm }\end{array}$ & $\begin{array}{c}\text { Distance } 10 \mathrm{~m} \\
\text { Depth } 0-30 \mathrm{~cm}\end{array}$ & $\begin{array}{c}\text { Distance } 20 \mathrm{~m} \\
\text { Depth } 0-30 \mathrm{~cm}\end{array}$ & $\begin{array}{c}\text { Control } \\
0-30 \mathrm{~cm}\end{array}$ \\
\hline $\mathrm{Ca}(\mathrm{mg} / \mathrm{kg})$ & $6.81 \pm 0.01$ & $6.08 \pm 0.01$ & $5.90 \pm 0.02$ & $1.14 \pm 0.02$ \\
\hline $\mathrm{Mg}(\mathrm{mg} / \mathrm{kg})$ & $8.85 \pm 0.03$ & $8.32 \pm 0.02$ & $7.11 \pm 0.01$ & $1.05 \pm 20.3$ \\
\hline $\mathrm{Na}(\mathrm{mg} / \mathrm{kg})$ & $7.18 \pm 0.02$ & $6.82 \pm 0.02$ & $6.21 \pm 0.01$ & $1.25 \pm 0.01$ \\
\hline $\mathrm{Pb}(\mathrm{mg} / \mathrm{kg})$ & $182.05 \pm 1.25$ & $144.85 \pm 2.20$ & $136.91 \pm 1.13$ & $23.68 \pm 0.04$ \\
\hline $\mathrm{Ni}(\mathrm{mg} / \mathrm{kg})$ & $118.35 \pm 0.23$ & $101.22 \pm 0.12$ & $89.76 \pm 0.06$ & $20.84 \pm 0.02$ \\
\hline $\mathrm{Cr}(\mathrm{mg} / \mathrm{kg}))$ & $115.86 \pm 0.08$ & $115.22 \pm 0.14$ & $98.11 \pm 0.03$ & $12.10 \pm 0.02$ \\
\hline $\mathrm{Cd}(\mathrm{mg} / \mathrm{kg})$ & $11.62 \pm 0.02$ & $11.02 \pm 0.02$ & $10.13 \pm 0.01$ & $0.16 \pm 0.01$ \\
\hline $\mathrm{Cu}(\mathrm{mg} / \mathrm{kg})$ & $550.92 \pm 1.12$ & $521.30 \pm 1.00$ & $426.25 \pm 0.32$ & $315.02 \pm 0.02$ \\
\hline $\mathrm{Fe}(\mathrm{mg} / \mathrm{kg})$ & $4387.52 \pm 3.12$ & $4263.23 \pm 2.51$ & $3981.51 \pm 2.23$ & $1892.43 \pm 1.33$ \\
\hline $\mathrm{Zn}(\mathrm{mg} / \mathrm{kg})$ & $311.06 \pm 0.12$ & $280.32 \pm 0.10$ & $251.76 \pm 0.16$ & $99.12 \pm 0.08$ \\
\hline $\mathrm{Mn}(\mathrm{mg} / \mathrm{kg})$ & $221.36 \pm 0.04$ & $202.41 \pm 0.11$ & $181.14 \pm 0.02$ & $87.42 \pm 0.04$ \\
\hline $\mathrm{N}(\mathrm{cmol} / \mathrm{kg})$ & $0.36 \pm 0.02$ & $0.25 \pm 0.01$ & $0.23 \pm 0.01$ & $0.20 \pm 0.00$ \\
\hline
\end{tabular}

Table 7. Geo-accumulation index factor based on distance and depth from landfill (North direction).

\begin{tabular}{|c|c|c|c|}
\hline Parameter & $\begin{array}{c}\text { Distance } 0 \\
\text { Depth } 0-30 \mathrm{~cm}\end{array}$ & $\begin{array}{c}\text { Distance } 10 \mathrm{~m} \\
\text { Depth } 0-30 \mathrm{~cm}\end{array}$ & $\begin{array}{c}\text { Distance } 20 \mathrm{~m} \\
\text { Depth } 0-30 \mathrm{~cm}\end{array}$ \\
\hline $\mathrm{Ca}$ & 1.09 & 0.98 & 0.77 \\
\hline $\mathrm{Mg}$ & 2.55 & 2.49 & 2.34 \\
\hline $\mathrm{Na}$ & 2.37 & 2.32 & 2.29 \\
\hline $\mathrm{Pb}$ & 0.02 & -0.33 & -0.46 \\
\hline $\mathrm{Ni}$ & 1.32 & 1.20 & 0.80 \\
\hline $\mathrm{Cr}$ & 2.18 & 2.05 & 1.86 \\
\hline $\mathrm{Cd}$ & 4.23 & 4.20 & 4.02 \\
\hline $\mathrm{Cu}$ & 2.47 & 2.36 & 1.57 \\
\hline $\mathrm{Fe}$ & 0.51 & 0.25 & 0.18 \\
\hline $\mathrm{Zn}$ & 0.56 & 0.19 & -0.39 \\
\hline $\mathrm{Mn}$ & 1.28 & 1.09 & 1.02 \\
\hline
\end{tabular}


Table 8. Geo-accumulation factor based on distance and depth from landfill (East direction).

\begin{tabular}{|c|c|c|c|}
\hline Parameter & $\begin{array}{c}\text { Distance } 0 \\
\text { Depth } 0-30 \mathrm{~cm}\end{array}$ & $\begin{array}{c}\text { Distance } 10 \mathrm{~m} \\
\text { Depth } 0-30 \mathrm{~cm}\end{array}$ & $\begin{array}{c}\text { Distance } 20 \mathrm{~m} \\
\text { Depth } 0-30 \mathrm{~cm}\end{array}$ \\
\hline $\mathrm{Ca}$ & 1.37 & 1.28 & 1.24 \\
\hline $\mathrm{Mg}$ & 1.76 & 1.67 & 1.44 \\
\hline $\mathrm{Na}$ & 1.30 & 1.25 & 1.16 \\
\hline $\mathrm{Pb}$ & 1.63 & 1.32 & 1.25 \\
\hline $\mathrm{Ni}$ & 1.30 & 1.14 & 1.02 \\
\hline $\mathrm{Cr}$ & 1.87 & 1.85 & 1.66 \\
\hline $\mathrm{Cd}$ & 3.99 & 3.94 & 3.77 \\
\hline $\mathrm{Cu}$ & 2.46 & 2.37 & 2.17 \\
\hline $\mathrm{Fe}$ & 0.53 & 0.47 & 0.44 \\
\hline $\mathrm{Zn}$ & 0.73 & 0.65 & 0.52 \\
\hline $\mathrm{Mn}$ & 0.49 & 0.40 & 0.26 \\
\hline
\end{tabular}

Table 9. Geo-accumulation factor based on distance and depth from landfill (south direction).

\begin{tabular}{|c|c|c|c|}
\hline Parameter & $\begin{array}{c}\text { Distance } 0 \\
\text { Depth } 0-30 \mathrm{~cm}\end{array}$ & $\begin{array}{c}\text { Distance } 10 \mathrm{~m} \\
\text { Depth } 0-30 \mathrm{~cm}\end{array}$ & $\begin{array}{c}\text { Distance } 20 \mathrm{~m} \\
\text { Depth } 0-30 \mathrm{~cm}\end{array}$ \\
\hline $\mathrm{Ca}$ & 1.12 & 2.61 & 0.88 \\
\hline $\mathrm{Mg}$ & 2.56 & 2.37 & 2.45 \\
\hline $\mathrm{Na}$ & 2.36 & 2.18 & 2.15 \\
\hline $\mathrm{Pb}$ & 1.89 & 1.67 & 1.47 \\
\hline $\mathrm{Ni}$ & 1.32 & 1.27 & 1.04 \\
\hline $\mathrm{Cr}$ & 2.17 & 1.96 & 1.79 \\
\hline $\mathrm{Cd}$ & 4.25 & 3.89 & 3.71 \\
\hline $\mathrm{Cu}$ & 2.49 & 2.07 & 1.50 \\
\hline $\mathrm{Fe}$ & 0.52 & 0.51 & 0.16 \\
\hline $\mathrm{Zn}$ & 0.78 & 0.50 & 0.52 \\
\hline $\mathrm{Mn}$ & 1.29 & 1.11 & 0.77 \\
\hline
\end{tabular}


Table 10. Geo-accumulation factor based on distance and depth from landfill (West direction).

\begin{tabular}{|c|c|c|c|}
\hline Parameter & $\begin{array}{c}\text { Distance } 0 \\
\text { Depth } 0-30 \mathrm{~cm}\end{array}$ & $\begin{array}{c}\text { Distance } 10 \mathrm{~m} \\
\text { Depth } 0-30 \mathrm{~cm}\end{array}$ & $\begin{array}{c}\text { Distance } 20 \mathrm{~m} \\
\text { Depth } 0-30 \mathrm{~cm}\end{array}$ \\
\hline $\mathrm{Ca}$ & 1.38 & 1.27 & 1.24 \\
\hline $\mathrm{Mg}$ & 1.72 & 1.66 & 1.50 \\
\hline $\mathrm{Na}$ & 1.34 & 1.29 & 1.20 \\
\hline $\mathrm{Pb}$ & 1.63 & 1.41 & 1.35 \\
\hline $\mathrm{Ni}$ & 1.33 & 1.18 & 1.06 \\
\hline $\mathrm{Cr}$ & 1.85 & 1.85 & 1.69 \\
\hline $\mathrm{Cd}$ & 3.88 & 3.83 & 3.74 \\
\hline $\mathrm{Cu}$ & 0.15 & 0.10 & -0.10 \\
\hline $\mathrm{Fe}$ & 0.44 & 0.41 & 0.34 \\
\hline $\mathrm{Zn}$ & 0.74 & 0.63 & 0.53 \\
\hline $\mathrm{Mn}$ & 0.52 & 0.43 & 0.32 \\
\hline
\end{tabular}

The present study shows the types of bacteria and their frequency of isolation from the waste dumpsite in Odo Aremu Ado Ekiti. The bacterial isolated from the dumpsite include the species of fungi identified were Aspergillus niger, Aspergillus flavus, Aspergillus fumigatus, Penicillium notatum, Mucor pusillus and Fusarium sporotrichioides.

The bacterial include Pseudomonas aeruginosa, Escherichia coli, Micrococcus sp, Bacillus megatarium, Chromatium violasceus, Bacillus subtilis, Klebsiella rhinosderomalis, Kurthia zopfii, Clostridium spirogenes, Bacillus licheniformis, Xanthomanas fragenee, Bacillus cereus, Gemella haemolysans and Serratia sp. were isolated from Odo Aremu Ado Ekiti dumpsite. 
Table 11. Cultural and Morphological Characteristics of bacterial isolates from the Dumpsites.

\begin{tabular}{|c|c|c|c|c|c|c|c|c|c|c|}
\hline $\begin{array}{l}\text { Probable } \\
\text { Organism }\end{array}$ & 1 & 2 & 3 & 4 & 5 & 6 & 7 & 8 & 9 & 10 \\
\hline Colour & White & White & White & Cream & Grey & Cream & White & Yellow & White & Cream \\
\hline Surface & Rough & Rough & Rough & Smooth & Rough & Rough & Rhizoid & Smooth & Rough & Smooth \\
\hline Edge & Rhizoid & Circular & Rhizoid & Entire & Lobate & Lobate & Lobate & Entire & Rhizoid & Entire \\
\hline Elevation & Flat & Raised & Flat & Flat & Flat & Flat & Flat & Raised & Flat & raised \\
\hline Shape & Rod & Ovoid & Rod & Rod & Rod & Rod & Rod & Rod & Rod & Rod \\
\hline Gram stain & + & - & + & - & + & + & + & - & + & - \\
\hline Catalase & + & + & + & - & + & + & + & + & + & - \\
\hline Starch hydrolysis & + & + & + & - & - & + & + & - & + & - \\
\hline Motility & + & + & + & - & + & + & + & - & + & - \\
\hline Spare & + & - & + & - & - & + & + & - & + & - \\
\hline Indole & - & - & - & - & - & - & - & - & - & - \\
\hline Methyl red & + & - & - & & + & - & - & - & - & - \\
\hline Vogesproskauer & - & - & - & - & - & - & - & - & + & - \\
\hline Glucose & - & A & A & - & $\mathrm{A}$ & $\mathrm{AG}$ & A & A & A & - \\
\hline Lactose & A & A & - & - & - & - & A & - & - & A \\
\hline Mannitol & - & A & A & - & - & A & A & $\mathrm{AG}$ & - & A \\
\hline Galactose & - & A & A & - & - & - & - & AY & A & A \\
\hline Fructose & A & - & A & A & - & - & - & - & AY & $\mathrm{AG}$ \\
\hline Maltose & A & - & A & - & A & A & $\mathrm{AG}$ & A & A & - \\
\hline Sucrose & $\mathrm{AG}$ & A & - & A & - & - & - & - & - & - \\
\hline Surbitol & A & - & - & A & - & - & $\mathrm{AG}$ & - & - & - \\
\hline
\end{tabular}

Key: += Positive; - = negative; $\mathrm{A}=$ Acid production; $\mathrm{AG}=$ Acid and gas production

$1=$ Bacillus megatarium, $2=$ Chromatium violasceus, $3=$ Bacillus subtilis, $4=$ Klebsiella rhinosderomalis, $5=$ Kurthia zopfii, $6=$ Clostridium spirogenes, $7=$ Bacillus licheniformis, $8=$ Xanthominas fragenee, $9=$ Bacillus cereus, 10 = Gemella haemolysans 


\section{DISCUSSION}

The study indicated that the concentration of heavy metals around the landfill vary per the sampling stations. Fe concentration was found to be highest at the Northern site, followed by $\mathrm{Mg}$ and $\mathrm{Ca}$. Other metals were found only in small concentration. The same was with the Eastern direction, which also showed Fe dominating compared to other metals. Analysis of soil samples in the southern direction indicated an increase in $\mathrm{Ca}$ and $\mathrm{Fe}$ as metals with the highest concentration. Collectively, the analysis of samples in the West direction, indicated high concentration of heavy metals compared to those in the North and East directions, except for Fe which was the most dominant heavy metals at all sampling stations around the landfill. Geo-accumulation index factor shown in Tables 7, 8, 9 and 10 respectively that the soils were uncontaminated to slightly contaminated by iron, zinc and lead but were moderately contaminated by nickel, and manganese in all the sites. Copper, chromium and cadmium showed generally highly contaminated except in few sites, where they showed high contamination.

All the bacterial isolates reported in this study have been reported to be associated with waste and waste biodegradation. Bacillus species were reported by (19), to be associated with waste Klebsiella species were also reported to be soil bacterial and they are potential pathogen. The presence of these potential pathogens reported in the present investigation may be attributed to the disposal of raw human faecal discharges and other human wastes at the waste - dumpsite. These observations compares favourably with the study conducted by (20)

\section{CONCLUSION}

Heavy metal pollution at the landfill is a chronic environmental problem. The pollution not only prevails around its vicinity during its period of operation but may linger on for a long time after the landfill or dumpsite ceased operations. To overcome the problem, the management aspect should be systematic and efficient not only at the early phase of operation but also during and after the landfill is closed from active operation. A regime of actions required to manage the issues of heavy metal pollution require substantial reduction of the waste sources through application of integrated management of waste through reducing generation of wastes at their respective source; recycling, compositing and thermal burning which could reduce the concentration of heavy metal in the wastes.

Finally, a sanitary landfill or dumpsite is a viable alternative to reduce the concentration of heavy metals for its design and water caption pond using High-Density Polyethylene (HDPE) may prevent leachate from seeping into the soil around the landfill and larger environment. 


\section{References}

[1] A. Wild, Soil and the Environment: An Introduction, Cambridge University press. (1995) 109-165.

[2] B. J. Alloway, D.C. Ayres, Chemical Principles of Environmental pollution, Blackie Academic and Professional. (1997) 53-359.

[3] M. W. Holgate, A perspective of environmental pollution, Cambridge University Press, Cambridge. (1979) 55-65.

[4] A. B. O. Oyediran, Waste generation and disposal in Nigeria a keynote address presented at a workshop on waste generation and disposal in Nigeria NEST Annual conference 1994, NEST Ibadan. (1994) 95-100.

[5] L. M. Shuman, J. Environ. Qua. 28 (1999) 1442-1447.

[6] K. C. Cameron, H. J. Di, R.G. McLaren, Australian Journal of Soil Res. 35 (1997) 995- 1035.

[7] V. Albina, R. Cioffi, B. De Vito, M. Marraccoli, L. Santoro, Stud. Environ. Sci. 60 (2008) 789-800.

[8] L. Rodriguez, E. Ruiz, J. Alonso-Azcarate, J. Rincon, J. Environ. Manage. 90(2) (2009) 1106-1116.

[9] L. L. Long, D.S. Shen, H.T. Wang, W.J. Lu, Y. Zhao, J. Hazard. Mater. 186(2-3) (2011) 1082-1087.

[10] J. Bronius, L. Vaida, Environm. Engin. Landsc. Manage. 17(3) (2009) 131-139.

[11] S. Prabpai, L. Charerntanyarak, B. Siri, M.R. Moore, B.N. Noller, Waste Manage. 29(8) (2009) 2316-2320.

[12] M. Natrah, H. Umar, R. SabihinAbd, Sains Malays. 38(6) (2009) 841-850.

[13] A. A. Oladipo, E.A. Oluyemi, I. A. Tubosun, M.K. Fasasi, F. I. Ibitoye, J. Appl. Sci. 5(1) (2005)75-79.

[14] W. F. Harrigan, M. F. McCance, Laboratory Methods in Food and Diary Microbiology. 8th Edition. Academic Press London. (1990).

[15] U. Forstner, W. Ahlf, W. Calmano, Sediment quality objectives and criteria development in Germany. Water Science and Technology 28 (1993)307.

[16] N. O. Eddy, Physicochemical parameter of water And heavy metal content of water, sediment and fishes from Qua Iboe River Estuary. M. Sc Thesis. Michael Okpara University of Agriculture, Umuchke, Nigeria, (2004)

[17] N. O. Eddy, S. A. Odoemelem, A. Mbaba, Electronic Journal of Environmental Agricultural and Food Chemistry 5(3) (2006) 1002-1019.

[18] S. Ogunyemi, R.O. Awodoyin, T. Opadeji, Emir. J. Agric. Sci. 15(2) (2003) 87-94. 
[19] M.A. Moqsud, A study on composting of solid waste. M.Sc. Eng. Thesis, Department of Civil Engineering, BUET, Bangladesh. (2003)

[20] R.J. Ash, B. Mauck, M. Morgan, Emerging Infectious Diseases. 8 (2002) 7-12

[21] Environmental Agency, (2007): Environmental Concentrations of Heavy Metals in UK Soil and Herbage. UK Soil and Herbage Pollutant Survey. Report No. 7. Bristol: Environment Agency. European Commission Director General Environment ECDGE, 2004. Heavy Metals and Organic Compounds from Wastes Used as Organic Fertilizers, Final Report, pp 73- 74, July. WPA Consulting Engineers Inc. Reference Number. TEND/AML/2001/07/20.

http://ec.europa.eu/environment/waste/compost/pdf/hm_finalreport.pdf 